\title{
Acid Properties of SAPO-34 Molecular Sieves with Different Si Contents Templated by Various Organic Structure-Directing Agents
}

\author{
Lei Wang ${ }^{1,2, \dagger}$, Tantan Sun ${ }^{1,3, \dagger}$, Nana Yan ${ }^{1,3}$, Xiaona Liu ${ }^{1,3}$, Chao Ma ${ }^{1,3,4}$, Shutao Xu ${ }^{1}$, Peng Guo ${ }^{1, *}$, \\ Peng Tian ${ }^{1}$, Zhongmin Liu ${ }^{1, *}$ \\ ${ }^{1}$ National Engineering Laboratory for Methanol to Olefins, Dalian National Laboratory for Clean Energy, Dalian Institute of \\ Chemical Physics, Chinese Academy of Sciences, Dalian 116023, Liaoning Province, China. \\ ${ }^{2}$ College of Chemistry, Henan Institute of Advanced Technology, Zhengzhou University, Zhengzhou 450001, China. \\ ${ }^{3}$ University of Chinese Academy of Sciences, Beijing 100049, China. \\ ${ }^{4}$ Zhang Dayu School of Chemistry, Dalian University of Technology, Dalian 116024, Liaoning Province, China.
}

\begin{abstract}
The acid properties of SAPO-34 molecular sieves (MSs), including the strength and density of Brönsted acids, have attracted enormous attention in past decades because of the excellent performance of SAPO-34 in industrial processes such as the methanol-to-olefins (MTO) process and the selective catalytic reduction of $\mathrm{NO}_{x}$ with $\mathrm{NH}_{3}\left(\mathrm{NH}_{3}-\mathrm{SCR}\right)$. Currently, pure-phase SAPO-34 MSs with different $\mathrm{Si}$ contents can be easily obtained by utilizing multifarious organic structure-directing agents (OSDAs). However, the resulting SAPO-34 MSs have different acid properties, which may affect their catalytic performance. Hence, correlating the acid properties with the OSDAs and Si contents is of significance to synthesize SAPO-34 MSs with the desired properties. Herein, the

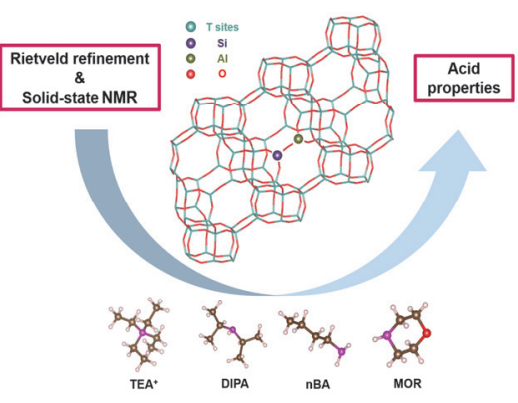
acid properties of four series of SAPO-34 MSs with varying Si contents synthesized using tetraethylammonium hydroxide (TEAOH), diisopropylamine (DIPA), $n$-butylamine (nBA), and morpholine (MOR) as the OSDAs were probed in detail by thermogravimetry (TG), Rietveld refinement, and solid-state nuclear magnetic resonance (ss-NMR) analyses. The strength and acid density were systematically investigated by exploring the host-guest interactions between the probed molecule $\mathrm{CD}_{3} \mathrm{CN}$ and the framework using ${ }^{1} \mathrm{H}$ magic angle spinning (MAS) NMR spectroscopy, and the local environments of $\mathrm{Si}$ were studied by ${ }^{29} \mathrm{Si}$ MAS NMR spectroscopy. The results of TG and Rietveld refinement showed that the SAPO-34 MSs templated by TEAOH and DIPA have only one OSDA per cha (one of the composite building units) cage in the longitudinal configuration, while those templated by nBA and MOR possess two OSDAs occluded in the cha cage in an up-and-down arrangement. Interestingly, the acid strength of SAPO-34 templated by TEAOH increased with increasing Si content, while the acid density remained almost unchanged. In contrast, the acid density of SAPO-34 templated by DIPA decreased evidently with an increase in the Si content, while the acid strength showed only a small variation. Among the other two samples, SAPO-34 templated by MOR has the most amounts of acid densities compared to SAPO-34 templated by nBA, while the strength is not superior. Thus, we conclude that the acid density is associated with the number of OSDAs in each cha cage and their protonation ability, while the difference in acid strength is attributed to the number of Si atoms at the edges of the Si islands. The findings of this study will provide insight into the acid properties of related crystalline porous materials.
\end{abstract}

Key Words: SAPO-34; OSDA; Acid property; ss-NMR; Rietveld refinement; Si distribution; Porous materials

Received: March 19, 2020; Revised: May 17, 2020; Accepted: May 18, 2020; Published online: May 25, 2020.

*Corresponding authors. Emails: pguo@dicp.ac.cn (P.G.); zml@dicp.ac.cn (Z.L.).

†These authors contributed equally to this work.

The project was supported by the National Natural Science Foundation of China (21972136, 21676262, 21991091), the CAS Pioneer Hundred Talents Program (Y706071202), the Dalian National Laboratory for Clean Energy, (DNL) Cooperation Fund, Chinese Academy of Sciences (DNL201908) and the Key Research Program of Frontier Sciences, Chinese Academy of Sciences (QYZDBSSW-JSC040).

国家自然科学基金(21972136, 21676262, 21991091), 中国科学院百人计划(Y706071202), 中国科学院洁净能源创新研究院合作基金(DNL201908)及 中国科学院前沿科学重点研究计划(QYZDBSSW-JSC040)资助项目

(C) Editorial office of Acta Physico-Chimica Sinica 


\title{
不同结构导向剂合成不同硅含量 SAPO-34 分子篮的酸性质
}

\author{
王磊 $1,2,+$, 孙医㔷 $1,3,+$, 闻娜娜 1,3 , 刘晓娜 1,3 , 马超 $1,3,4$, 徐舒涛 ${ }^{1}$, 郭鹏 $1,{ }^{*}$, 田鹏 ${ }^{1}$, 刘中民 1,* \\ 1 中国科学院大连化学物理研究所, 甲醇制烯烃国家工程实验室, 洁净能源国家实验室, 辽宁大连 116023 \\ 2 郑州大学化学学院, 河南先进技术研究所, 郑州 450001 \\ 3 中国科学院大学, 北京 100049 \\ ${ }^{4}$ 大连理工大学张大煌学院, 辽宁 大连 116024
}

摘要: SAPO-34分子篮由于其独特的拓扑结构和适宜的酸性, 在以甲醇制烯烃(MTO)和氨气选择性催化还原 $\mathrm{NO}_{x}\left(\mathrm{NH}_{3}-\right.$ $\mathrm{SCR}$ )为代表的系列催化反应中显示了优良的性能, 因此吸引了研究者的广泛关注。但是, 在合成过程中如何通过选择有 机模板和控制硅含量来得到合适酸量的SAPO-34催化剂是极具挑战的。本文中, 四个系列的SAPO-34分子篮, 即分别由 四乙基氢氧化铵(TEAOH)、二异丙胺(DIPA)、正丁胺(nBA)和吗啉(MOR)为有机模板剂合成不同硅含量的样品, 通过热 重量分析(TG), 结构精修和固态核磁进行了研究。TG和结构精修结果显示在TEAOH和DIPA合成的SAPO-34分子篮cha (一种复合结构单元)笼子中只有一个结构导向剂而MOR和nBA合成的SAPO-34分子篮的cha笼中有两个。采用固态核磁 氢谱( ${ }^{1} \mathrm{H}$ ss-NMR)探究碱性探针分子気代乙腈 $\left(\mathrm{CD}_{3} \mathrm{CN}\right.$ )和分子篎骨架之间主客体的相互作用, 并对其酸性(酸量和酸强度) 进行了系统的研究。例如, TEAOH合成的SAPO-34分子篮随着硅含量的增加酸强度增加而酸量却保持着不变。而DIPA 合成的SAPO-34, 与前者存在较大的差异, 即随着硅含量的上升, 酸量显著下降而酸强度只发生了微小的变化。该工作 为SAPO-34分子篮催化剂酸性的定向调变提供了理论基础。

关键词: SAPO-34; 有机模板剂; 酸性质; 固体核磁; 结构精修; 硅分布; 多孔材料 中图分类号: 0641

\section{Introduction}

Silicoaluminophosphate (SAPO) molecular sieves (MSs), which were firstly reported by Union Carbide, are a critically significant group in the class of crystalline microporous materials ${ }^{1}$. The tetrahedra $\mathrm{TO}_{4}(\mathrm{~T}=\mathrm{Al}, \mathrm{P}$, and $\mathrm{Si})$ can be regarded as the basic building units, which will be further assembled through the corning-sharing, consequently, generating a variety of SAPOs with different topologies and compositions. Until now, 41 SAPO MSs with well-defined channels or cages in molecular size have been reported in the pieces of literatures ${ }^{2,3}$. Among these SAPOs, SAPO-34, a smallpore SAPO MS with the CHA (a framework type code) topology, has been explored to be a promising material for the methanol-to-olefin (MTO) reaction ${ }^{4,5}, \mathrm{NH}_{3}$ selective catalytic reduction $\left(\mathrm{NH}_{3}-\mathrm{SCR}\right)^{6,7}$ and $\mathrm{CO}_{2} / \mathrm{CH}_{4}$ separation ${ }^{8,9}$, due to its unique cage-based crystallographic structure with small-pore openings and moderate Brönsted acids (BAs).

As a solid acid catalyst, the acidic properties of SAPO-34 play significant roles in its application performance. For instance, a study by Peng et al. ${ }^{10}$ found that a suitable BAs in SAPO-34 can effectively prolong the catalyst lifetime and enhance the total light olefins selectivity due to the suppression of hydrogen transfer reaction during the methanol conversion. Besides, Wang et al. ${ }^{11}$ investigated the role of $\mathrm{BAs}$ in the $\mathrm{NH}_{3}-\mathrm{SCR}$ by employing the different potassium loadings. It is concluded that the $\mathrm{NH}_{3}$ was firstly adsorbed on the BAs and gradually migrating to the active sites. The BAs could be the supplier of $\mathrm{NH}_{3}$ for the $\mathrm{NH}_{3}-\mathrm{SCR}$ at the high temperature. Therefore, a further investigation of BAs in SAPO-34 should be of great importance. Generally, the BAs in SAPOs are generated by the introduction of $\mathrm{Si}$ atoms into the framework of neutral aluminophosphate (AlPO) molecular sieves. From the perspective of synthesis, the introduction of $\mathrm{Si}$ atoms is highly associated with the organic structure-directing agent (OSDA) and the Si contents in precursor gels. The choice of OSDA has been considered as an important factor to successfully synthesize SAPO materials. Now, it seems that the preparation of SAPO$34 \mathrm{~s}$ cannot be a challenge. A large number of commercialized OSDAs such as $n$-butylamine (nBA), diisopropylamine (DIPA), triethylamine (TEA), tetraethylammonium hydroxide (TEAOH) and morpholine (MOR) have been utilized for the successful synthesis of SAPO-34 MSs ${ }^{12-16}$. However, when these SAPO$34 \mathrm{~s}$ are used as catalysts, they display the distinct catalytic performance. For example, a study by Woo et al. ${ }^{17}$ showed that SAPO-34 templated by MOR, TEA or TEAOH with similar Si contents would lead to the different catalytic performance and stability in $\mathrm{NH}_{3}-\mathrm{SCR}$, which were highly related to the BAs properties. SAPO-34s templated by a small size MOR as OSDA were delicate after the low-temperature treatment.

Moreover, for a specific OSDA, two different substitution mechanisms, namely SM II and SM III, will occur with the addition of Si contents. In SM II, one Si atom substitutes for one $\mathrm{P}$ atom while in SM III, adjacent $\mathrm{Al}$ and $\mathrm{P}$ atoms are replaced by a pair of $\mathrm{Si}$ atoms. Thus, $\mathrm{Si}$ atoms will settle down in various local environments, that is, isolated $\mathrm{Si}(\mathrm{Si}(4 \mathrm{Al}))$ and $\mathrm{Si}$ islands (Si(3Al), $\mathrm{Si}(2 \mathrm{Al}), \mathrm{Si}(1 \mathrm{Al})$ and $\mathrm{Si}(0 \mathrm{Al})){ }^{18}$. Notably, the $\mathrm{Si}(0 \mathrm{Al})$ 
is a neutral structural fragment and will not generate BAs. Furthermore, it is well-accepted that the acid strength of BAs in SAPO MSs follows the order: $\mathrm{Si}(1 \mathrm{Al})>\mathrm{Si}(2 \mathrm{Al})>\mathrm{Si}(3 \mathrm{Al})>$ $\mathrm{Si}(4 \mathrm{Al}){ }^{19}$. Therefore, the BAs properties of SAPO-34 should be greatly influenced by the choice of OSDAs and the Si content in the framework.

For the proton-form SAPO samples, the acid properties, including the density and strength, can generally be investigated by temperature-programmed desorption of ammonia $\left(\mathrm{NH}_{3}-\right.$ TPD), infrared spectroscopy (IR), and solid-state nuclear magnetic resonance (ss-NMR) in combination with a proper probe molecule. Compared with the first two techniques, ssNMR has been considered a more accurate one to clarify the acid strength and density with tiny differences. Moreover, the synergy effect of OSDA and Si content for a specific SAPO material with desirable properties can be carried out through probing the locations of OSDAs and host-guest interaction in the as-made sample. For example, recently, our group has utilized Rietveld refinement against powder X-ray diffraction (PXRD) to explore the OSDA positions and their interactions with SAPO framework in the as-made DNL-6 (SAPO form RHO topology). Subsequently, based on the structural features of OSDAs revealed from refinement results, we identified a series of commercialized OSDAs for the targeted synthesis of DNL-6s with tunable Si contents ${ }^{20}$.

Herein, four series of SAPO-34s with low-, medium-, high-Si contents have been prepared by employing TEAOH, DIPA, $\mathrm{nBA}$, and MOR as OSDAs, respectively. The acid properties (the density and strength of BAs) of these samples and how to tune them through judiciously selecting OSDAs have been further explored in detail by ${ }^{1} \mathrm{H}$ MAS NMR spectra combined with the adsorption of $\mathrm{d}_{3}$-acetonitrile $\left(\mathrm{CD}_{3} \mathrm{CN}\right)$ and Rietveld refinement against PXRD data, respectively.

\section{Experimental}

\subsection{Sample preparations}

All SAPO-34s used here were prepared by hydrothermal method. The detailed gel compositions can be obtained in Table
1. The synthesis procedures are described as follows: Phosphoric acid (80\%) was firstly added into distilled water and then stirred with pseudo-boehmite $(67 \%)$ for a moment. One of the silicon sources, including tetraethyl orthosilicate (TEOS, 96\%), fumed silica (98\%) or silica gel (27\%), was subsequently added into the gel with continuous stirring. 5\% seeds, which were based on the weight of $\mathrm{Al}_{2} \mathrm{O}_{3}$ in the synthesis system, would be added into the gel if necessary. The homogeneous gel was transformed into a stainless-steel autoclave, crystallizing for a $24 \mathrm{~h}$ at $200{ }^{\circ} \mathrm{C}$. The solid products were obtained after centrifugation, washed with distilled water and dried in air at $120^{\circ} \mathrm{C}$ for at least $4 \mathrm{~h}$.

The proton-form SAPO-34s were obtained through the calcination of crystallized as-made products at $550{ }^{\circ} \mathrm{C}$. Then, the samples were dehydrated typically at $420^{\circ} \mathrm{C}$ under vacuum $(<$ $\left.10^{-3} \mathrm{~Pa}\right)$ over $12 \mathrm{~h}$ for NMR measurements. After the dehydration process, a certain amount of probe molecules $\mathrm{CD}_{3} \mathrm{CN}$ (99.9\% deuterated) were condensed and frozen inside the tube by liquid nitrogen. The sample was equilibrated for $1 \mathrm{~h}$ at $50{ }^{\circ} \mathrm{C}$ and degassed at $50{ }^{\circ} \mathrm{C}$ for $30 \mathrm{~min}$ to remove the physically absorbed probe molecules.

The hydrochloric acid treatment was carried out as follows: as-made products (SAPO-34-DIPA-L and SAPO-34-DIPA-H) were mixed with $0.58 \mathrm{~mol} \cdot \mathrm{L}^{-1}$ hydrochloric acid with the liquidsolid ratio 10 . After stirring vigorously for $2.5 \mathrm{~h}$ at $80^{\circ} \mathrm{C}$, the residue was filtered, washed, and dried for further characterizations.

\subsection{Characterization}

Initial PXRD data was collected by a PANalytical X'Pert PRO $\mathrm{X}$-ray diffractometer with $\mathrm{Cu} K_{\alpha}$ radiation $(\lambda=1.5418 \AA(1 \AA=$ $0.1 \mathrm{~nm})$ ). The data used for Rietveld refinement was collected on the STOE STADI P ESSENTIAL X-ray diffractometer, which is equipped with a Mythen II detector in the DebyeScherrer mode with the pure $\mathrm{Cu} K_{\alpha 1}$ radiation $(\lambda=1.5406 \AA)$. The capillary diameter is $0.2 \mathrm{~mm}$ and the angle range is from $5^{\circ}$ to $120^{\circ}$ with a $0.015^{\circ}$ step size at room temperature. The total collecting time of one dataset is 20-25 h. A PANalytical Axios advanced X-ray fluorescence spectroscopy (XRF) was employed to obtain the composition information of the elemental

Table 1 Gel compositions and unit cell compositions of as-made samples.

\begin{tabular}{|c|c|c|c|c|}
\hline Samples & Si contents $/ \%^{a}$ & Gel composition $^{b}$ & Unit cell composition $^{c}$ & Average number of OSDA per cha cage \\
\hline SAPO-34-TEAOH-L & 8.7 & 2TEAOH:0.3 $\mathrm{SiO}_{2}: 1 \mathrm{P}_{2} \mathrm{O}_{5}: 1 \mathrm{Al}_{2} \mathrm{O}_{3}: 50 \mathrm{H}_{2} \mathrm{O}$ & $\left|\mathrm{TEAOH}_{2.9} \mathrm{H}_{2} \mathrm{O}_{5.4}\right|\left[\mathrm{Si}_{3.1} \mathrm{Al}_{17.5} \mathrm{P}_{15.4} \mathrm{O}_{72}\right]$ & 1.0 \\
\hline SAPO-34-TEAOH-M & 15.1 & 2TEAOH:0.6 $6 \mathrm{SiO}_{2}: 1 \mathrm{P}_{2} \mathrm{O}_{5}: 1 \mathrm{Al}_{2} \mathrm{O}_{3}: 50 \mathrm{H}_{2} \mathrm{O}$ & $\left|\mathrm{TEAOH}_{2.9} \mathrm{H}_{2} \mathrm{O}_{5.6}\right|\left[\mathrm{Si}_{5.4} \mathrm{Al}_{16.5} \mathrm{P}_{14.1} \mathrm{O}_{72}\right]$ & 1.0 \\
\hline SAPO-34-TEAOH-H & 22.0 & 2TEAOH:1.1 $1 \mathrm{SiO}_{2}: 1 \mathrm{P}_{2} \mathrm{O}_{5}: 1 \mathrm{Al}_{2} \mathrm{O}_{3}: 50 \mathrm{H}_{2} \mathrm{O}$ & $\left|\mathrm{TEAOH}_{2.9} \mathrm{H}_{2} \mathrm{O}_{4.1}\right|\left[\mathrm{Si}_{7.9} \mathrm{Al}_{15.7} \mathrm{P}_{12.4} \mathrm{O}_{72}\right]$ & 1.0 \\
\hline SAPO-34-DIPA-L & 8.7 & 3DIPA:0.3 $\mathrm{SiO}_{2}: 1 \mathrm{P}_{2} \mathrm{O}_{5}: 1 \mathrm{Al}_{2} \mathrm{O}_{3}: 50 \mathrm{H}_{2} \mathrm{O}$ & $\left|\mathrm{DIPA}_{3.3} \mathrm{H}_{2} \mathrm{O}_{8.2}\right|\left[\mathrm{Si}_{3.1} \mathrm{Al}_{17.5} \mathrm{P}_{15.4} \mathrm{O}_{72}\right]$ & 1.1 \\
\hline SAPO-34-DIPA-M & 15.3 & 3DIPA:0.6 $\mathrm{SiO}_{2}: 1 \mathrm{P}_{2} \mathrm{O}_{5}: 1 \mathrm{Al}_{2} \mathrm{O}_{3}: 50 \mathrm{H}_{2} \mathrm{O}$ & $\left|\mathrm{DIPA}_{3.4} \mathrm{H}_{2} \mathrm{O}_{8.9}\right|\left[\mathrm{Si}_{5.5} \mathrm{Al}_{16.6 .} \mathrm{P}_{13.9} \mathrm{O}_{72}\right]$ & 1.1 \\
\hline SAPO-34-DIPA-H & 22.1 & 3DIPA:1.1 $\mathrm{SiO}_{2}: 1 \mathrm{P}_{2} \mathrm{O}_{5}: 1 \mathrm{Al}_{2} \mathrm{O}_{3}: 50 \mathrm{H}_{2} \mathrm{O}$ with $5 \%$ seeds ${ }^{\mathrm{d}}$ & $\left|\mathrm{DIPA}_{3.3} \mathrm{H}_{2} \mathrm{O}_{8.3}\right|\left[\mathrm{Si}_{8.0} \mathrm{Al}_{15,1} \mathrm{P}_{12.9} \mathrm{O}_{72}\right]$ & 1.1 \\
\hline SAPO-34-nBA-M & 16.0 & 2nBA:0.6 $\mathrm{SiO}_{2}: 0.8 \mathrm{P}_{2} \mathrm{O}_{5}: 1 \mathrm{Al}_{2} \mathrm{O}_{3}: 50 \mathrm{H}_{2} \mathrm{O}$ with $5 \%$ seeds & $\left|\mathrm{nBA}_{5.6} \mathrm{H}_{2} \mathrm{O}_{2.7}\right|\left[\mathrm{Si}_{5.8} \mathrm{Al}_{17.3} \mathrm{P}_{12.9} \mathrm{O}_{72}\right]$ & 1.9 \\
\hline SAPO-34-nBA-H & 23.8 & 2nBA:1.0SiO $2: 0.8 \mathrm{P}_{2} \mathrm{O}_{5}: 1 \mathrm{Al}_{2} \mathrm{O}_{3}: 50 \mathrm{H}_{2} \mathrm{O}$ with $5 \%$ seeds & $\left|\mathrm{nBA}_{5.8} \mathrm{H}_{2} \mathrm{O}_{1.4}\right|\left[\mathrm{Si}_{8.6} \mathrm{Al}_{16.0} \mathrm{P}_{11.4} \mathrm{O}_{72}\right]$ & 1.9 \\
\hline SAPO-34-MOR-M & 15.8 & 2MOR:0.7 $\mathrm{SiO}_{2}: 0.8 \mathrm{P}_{2} \mathrm{O}_{5}: 1 \mathrm{Al}_{2} \mathrm{O}_{3}: 50 \mathrm{H}_{2} \mathrm{O}$ with $5 \%$ seeds & $\left|\mathrm{MOR}_{5.7} \mathrm{H}_{2} \mathrm{O}_{7.1}\right|\left[\mathrm{Si}_{5.7} \mathrm{Al}_{16.8} \mathrm{P}_{13.5} \mathrm{O}_{72}\right]$ & 1.9 \\
\hline
\end{tabular}

${ }^{\mathrm{a}}$ Determined with XRF and $\mathrm{Si}$ contents $=\mathrm{Si} /(\mathrm{Si}+\mathrm{Al}+\mathrm{P})$ in molar ratio. ${ }^{\mathrm{b}}$ Silicon sources for SAPO-34-TEAOH, SAPO-34-DIPA, SAPO-34-nBA and SAPO-34-MOR are fumed silica, TEOS, silica gel and silica gel, respectively. ${ }^{\mathrm{c}}$ Determined with XRF and TG. ${ }^{\mathrm{d}}$ The gel composition of the seeds is 
in the samples. A TA Q-600 analyzer was used for thermogravimetry analysis (TGA) under $100 \mathrm{~mL} \cdot \mathrm{min}^{-1}$ air condition and the heating rate was set at $10^{\circ} \mathrm{C} \cdot \mathrm{min}^{-1}$. The morphologies of samples were observed by scanning electron microscope (SEM) on a Hitachi SU8020 microscope. The solidstate NMR experiments were carried out on a Bruker Avance III 600 spectrometer equipped with a $14.1 \mathrm{~T}$ wide-bore magnet and a $4 \mathrm{~mm}$ WVT MAS probe. The resonance frequencies were selected at $600.13,242.93,156.4$ and $119.2 \mathrm{MHz}$ for ${ }^{1} \mathrm{H},{ }^{31} \mathrm{P}$, ${ }^{27} \mathrm{Al}$, and ${ }^{29} \mathrm{Si}$, respectively. ${ }^{1} \mathrm{H}$ MAS NMR spectra were recorded using a single pulse sequence with a $\pi / 4$ pulse of $1.8 \mu \mathrm{s}$ and a $10 \mathrm{~s}$ recycle delay at a spinning rate of $12 \mathrm{kHz}$, using adamantane (1.74 ppm) as the chemical shift reference. For the quantification of BA density, all samples were weighed accurately at first and their ${ }^{1} \mathrm{H}$ MAS NMR spectra were processed by Dmfit software with Gaussian-Lorentz line shapes, using adamantane as the quantitative external standard. ${ }^{27} \mathrm{Al}$ MAS NMR experiments were performed with a spinning rate of $12 \mathrm{kHz}$ using one pulse sequence. 256 scans were accumulated with a $\pi / 8$ pulse width of $0.75 \mu$ s and a 2 s recycle delay. Chemical shifts were referenced to $\left(\mathrm{NH}_{4}\right) \mathrm{Al}\left(\mathrm{SO}_{4}\right)_{2} \cdot 12 \mathrm{H}_{2} \mathrm{O}$ at $-0.4 \mathrm{ppm} .{ }^{29} \mathrm{Si}$ MAS NMR spectra were recorded with a spinning rate of $8 \mathrm{kHz}$ using high-power proton decoupling. 4096, 3072 or 2048 scans were accumulated with a $\pi / 4$ pulse width of $2.5 \mu$ s and a $10 \mathrm{~s}$ recycle delay. Chemical shifts were referenced to kaolinite at $-91.5 \mathrm{ppm}$. The ${ }^{29} \mathrm{Si}$ MAS NMR spectra were also processed by Dmfit software with GaussianLorentz line shapes. ${ }^{31} \mathrm{P}$ MAS NMR spectra were recorded with a spinning rate of $12 \mathrm{kHz}$ using high-power proton decoupling. 64 scans were accumulated with a $\pi / 4$ pulse width of $2.4 \mu$ s and a $10 \mathrm{~s}$ recycle delay. Chemical shifts were referenced to $85 \%$ $\mathrm{H}_{3} \mathrm{PO}_{4}$ at 0 ppm.

\subsection{Rietveld refinement}

The experimental PXRD patterns of SAPO-34-TEAOH-L and SAPO-34-MOR-M were collected as mentioned before and would be further refined in software TOPAS $5.0^{21}$. The simulated PXRD data of the ideal CHA framework, downloaded from International Zeolite Association (IZA) Structure

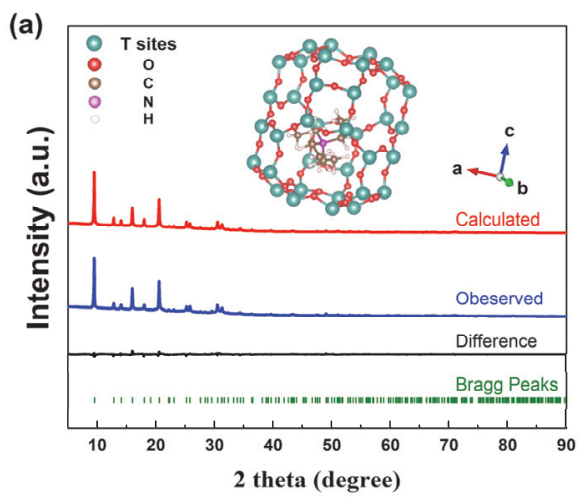

Database, could be calculated. The space group of idealized CHA structure is $R \overline{3} m$ (No. 166), where there are one $\mathrm{T}$ atom and four $\mathrm{O}$ atoms in the asymmetric unit. However, due to the alternating distribution of $\mathrm{Al}$ and $\mathrm{P}$ in SAPO-34, the space group would be reduced to $R \overline{3}$ (No. 148). SAPO-34-TEAOH-L belongs to this category. However, for the SAPO-34-MOR-M sample, an attempt to do Le Bail profile fitting using hexagonal unit cell parameters failed. Therefore, a SAPO form triclinic CHA structural model was adopted, which had been reported in the literatures ${ }^{22,23}$. Finally, the initial positions of TEAOH and MOR would be located by simulated annealing algorithm.

\section{Results and discussion}

Four series of SAPO-34 MSs with varied in Si contents templated by TEAOH, DIPA, nBA, and MOR were successfully synthesized (Table 1). The SEM images and preliminary PXRD of these samples are shown in Figs. S1 and S2 (Supporting Information (SI)). In order to better illustrate acid properties among these SAPO-34 MSs, samples of interest templated by TEAOH will be explained in detail. TEAOH has been regarded as an efficient OSDA to direct the synthesis of SAPO-34 with an adjustable Si content ${ }^{24}$. Three samples in this series with different Si contents of $8.7 \%, 15.1 \%$, and $22.0 \%$ have been obtained by modulating the Si contents of the gel composition, and denoted as SAPO-34-TEAOH-L, SAPO-34-TEAOH-M, and SAPO-34-TEAOH-H, respectively. The unit cell compositions of this series of samples deduced from XRF and TG results are also listed in Table 1. For these samples, it is interesting to note that there is only one OSDA in per cha cage, regardless of the Si contents. In order to locate the positions of OSDAs, Rietveld refinement combined with simulated annealing algorithm are employed. In our previous study, this combined methodology has been utilized for determining the atomic coordinates of guest species within channels or cavities and their interactions with the host framework ${ }^{20,25}$. Therefore, in this work, Rietveld refinement combined with simulated annealing algorithms also determines the positions of TEAOH. As shown in Fig. 1 and Table S1 (SI), the final Rietveld

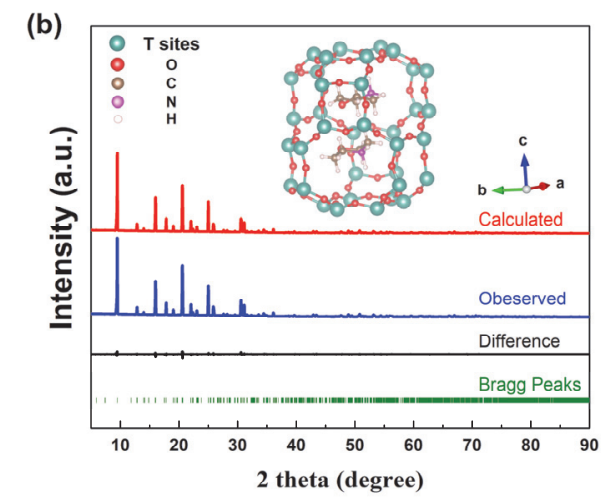

Fig. 1 (a) Rietveld refinement plots of SAPO-34-TEAOH-L. The SAPO-34-TEAOH-L is selected for this refinement process due to its better crystallinity. (b) Rietveld refinement plots of SAPO-34-MOR-M. The calculated, observed and difference curves are in red, blue and black, respectively. The short vertical lines are the positions of Bragg peaks. The insert sketches are locations of TEAOH and MOR in cha cages. 
refinement results converge to $R_{\mathrm{p}}=2.97 \%, R_{\mathrm{wp}}=4.11 \%, R_{\mathrm{bragg}}=$ $2.09 \%$, and $\mathrm{GOF}=2.619$, respectively.

The crystallographic structure revealed from Rietveld refinement shows there is only one $\mathrm{TEA}^{+}$occluded in the cha cage, which is consistent with the TG result. Moreover, TEAOH consists of an inborn cationic group $\mathrm{TEA}^{+}$and thus has a significant advantage to balance the negative charges from the CHA framework. Based on this, the density of BAs in the three samples should be the same. To verify this hypothesis and investigate the precise acid properties of the SAPO-34-TEAOH series, we sought the assistance of ss-NMR since the acid density and strength can be measured by ${ }^{1} \mathrm{H}$ MAS NMR spectra and combining with probe molecules, respectively. As shown in Fig. 2a, densities of BAs in SAPO-34-TEAOH-L, SAPO-34TEAOH-M, and SAPO-34-TEAOH-H are identical, just varied very little from 1.03 to $0.93 \mathrm{mmol} \cdot \mathrm{g}^{-1}$, although the Si contents are tripled. This is attributed to the fact that the amount of protonated OSDA in these three samples, which will balance the negative charge from the host framework, is fixed. This interesting result is consistent with our aforementioned hypothesis. The ${ }^{29} \mathrm{Si}$ MAS NMR spectra of the four series of SAPO-34 MSs are shown in Fig. 3. The resonance signals appeared at $-91,-96,-101,-106$, and $-111 \mathrm{ppm}$ are attributed to $\mathrm{Si}(4 \mathrm{Al}), \mathrm{Si}(3 \mathrm{Al}), \mathrm{Si}(2 \mathrm{Al}), \mathrm{Si}(1 \mathrm{Al})$, and $\mathrm{Si}(0 \mathrm{Al})$, respectively. According to the ${ }^{29}$ Si MAS NMR spectra of SAPO-34-TEAOH series, Si islands ( $-96--111 \mathrm{ppm})$ enhanced greatly along with the increase of Si contents (Fig. 3a). Only one positive TEA ${ }^{+}$ion is occluded in each cha cage and no more positive charges can balance the framework negative charges, consequently, increased $\mathrm{Si}$ can only be incorporated in the form of Si islands. (a)

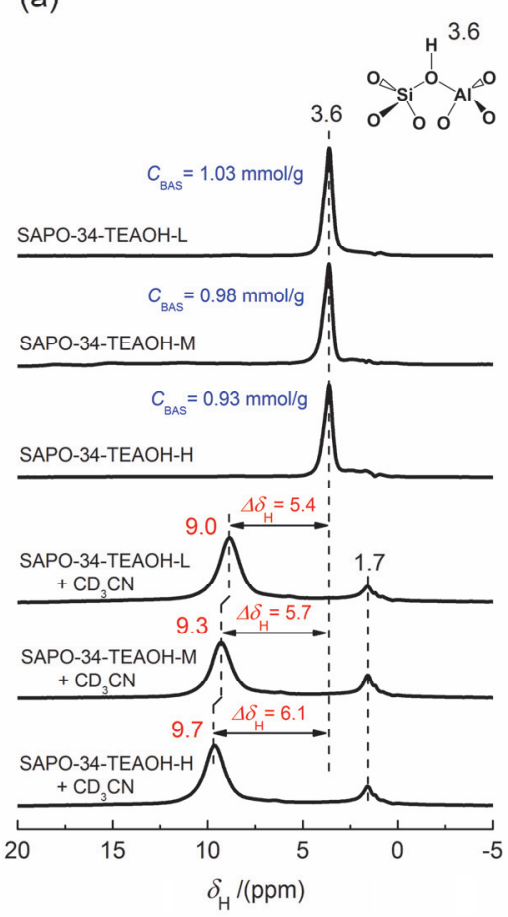

(b)

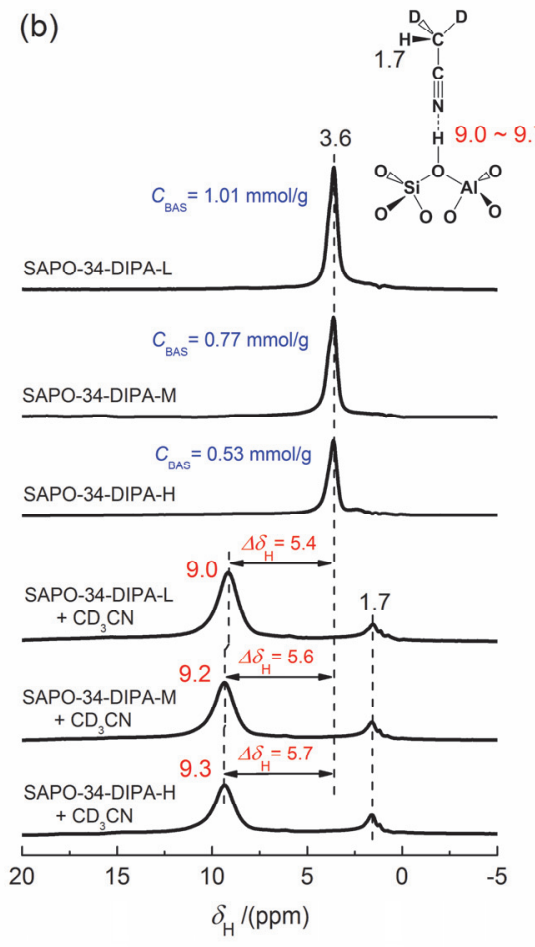

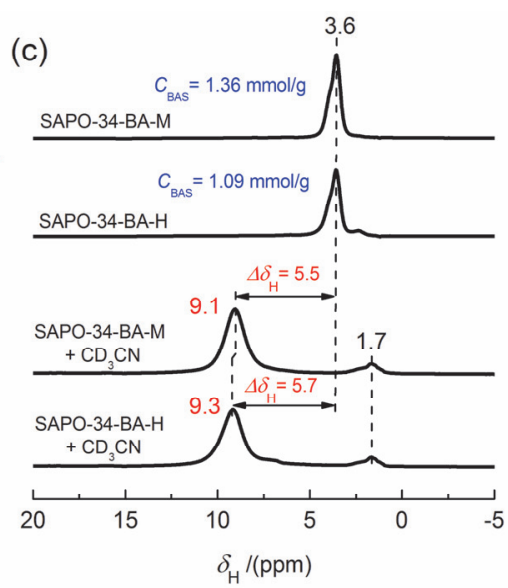

(d)

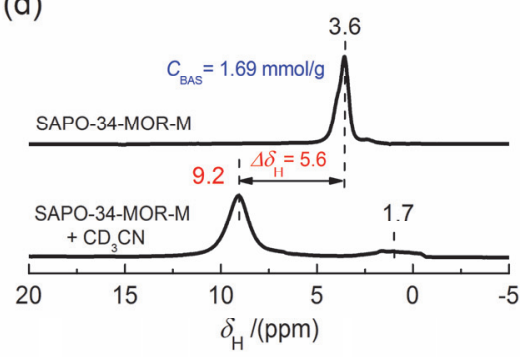

Fig. $2{ }^{1}$ H MAS NMR spectra of the dehydrated proton-form SAPO-34 (top) that templated by (a) TEAOH, (b) DIPA, (c) nBA and (d) MOR, and the corresponding ${ }^{1} \mathrm{H}$ spectra after loading (bottom) with deuterated acetonitrile $\left(\mathrm{CD}_{3} \mathrm{CN}\right)$.

(a)

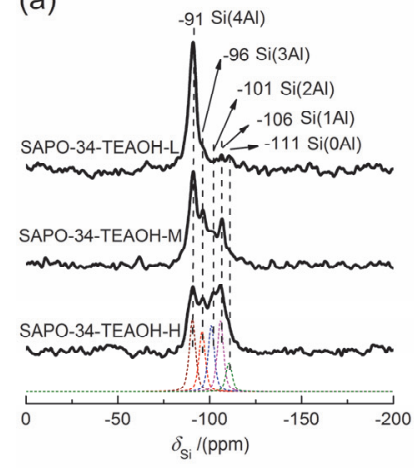

(b)

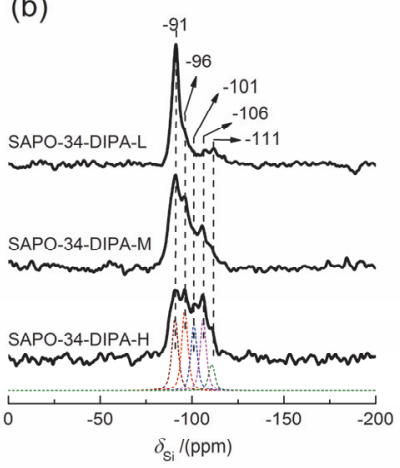

(c)

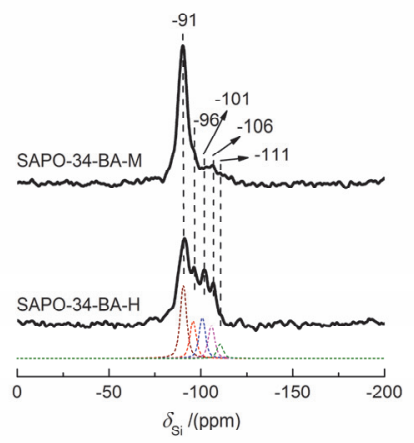

(d)

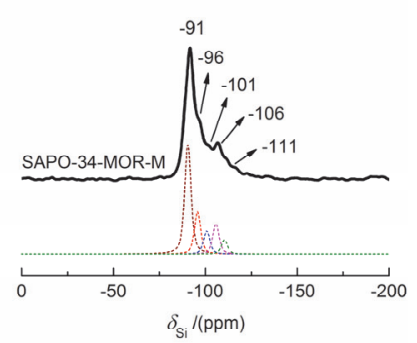

Fig. $3{ }^{29}$ Si MAS NMR spectra of the dehydrated proton-form SAPO-34 that templated by (a) TEAOH, (b) DIPA, (c) nBA, and (d) MOR. 
The acid strength was further investigated by adsorbing probe molecule $\mathrm{CD}_{3} \mathrm{CN}$ on BA sites. As a weak base, acetonitrile is sensitive to discriminate BAs. When acetonitrile interacts with BA sites via hydrogen bonding (illustrated as an inset in Fig. 2), the ${ }^{1} \mathrm{H}$ resonance will be shifted to the lower field ${ }^{26,27}$. Therefore, this adsorbate-induced resonance shift $\Delta \delta_{\mathrm{H}}$ is utilized for probing the acid strength. A larger value in $\Delta \delta_{\mathrm{H}}$ indicates a higher acid strength. As shown in Fig. 2a, upon adsorbing $\mathrm{CD}_{3} \mathrm{CN}$ on BA sites of SAPO-34-TEAOH-L, SAPO-34TEAOH-M, and SAPO-34-TEAOH-H, the resonance shifts $\Delta \delta_{\mathrm{H}}$ of 5.4, 5.7, and $6.1 \mathrm{ppm}$ are deduced, indicative of an increased strength of BAs for these three samples. As mentioned in the introduction, the acid strength of SAPOs is highly related to the Si islands $(\mathrm{Si}(3-1 \mathrm{Al}))$, therefore, the acid strength in SAPOs would be higher when $\mathrm{Si}$ island formed. However, compared with the other series, the acid strength is enhanced more evident for SAPO-34s template by TEAOH, which will be discussed further as follows. In a short summary, combining multitechnique approaches, acid densities in SAPO-34-TEAOH MSs are almost identical, while acid strengths enhanced evidently with the increase of Si contents.

Another series of SAPO-34 MSs with different Si contents templated by DIPA were prepared, and denoted as SAPO-34-DIPAL, SAPO-34-DIPA-M, and SAPO-34-DIPA-H, respectively. Their unit cell chemical compositions are listed in Table 1 as well. There is also one OSDA per cage in the SAPO-34 templated by DIPA ${ }^{25}$. Unprecedentedly, as shown in Fig. 2b, the density of BAs in SAPO-34-DIPA series is monotonically decreased with the increase of Si contents, which is distinct from the results observed in the SAPO-34-TEAOH series. According to the ${ }^{29} \mathrm{Si}$ MAS NMR spectra, the increase of Si contents also results in more $\mathrm{Si}$ islands as shown in Fig. 3b. Moreover, the resonance shifts $\Delta \delta_{\mathrm{H}}$ for SAPO-34-DIPA-L, SAPO-34-DIPA-M, and SAPO-34-DIPA-H with the adsorption of $\mathrm{CD}_{3} \mathrm{CN}$ are 5.4, 5.6, and 5.7 ppm, respectively (Fig. 3a). This indicates that acid strengths of SAPO-34-DIPA series vary relatively little with the increase of Si contents. It seems that the BA properties of SAPO34-DIPAs are quite different from the scenario observed in

(a)

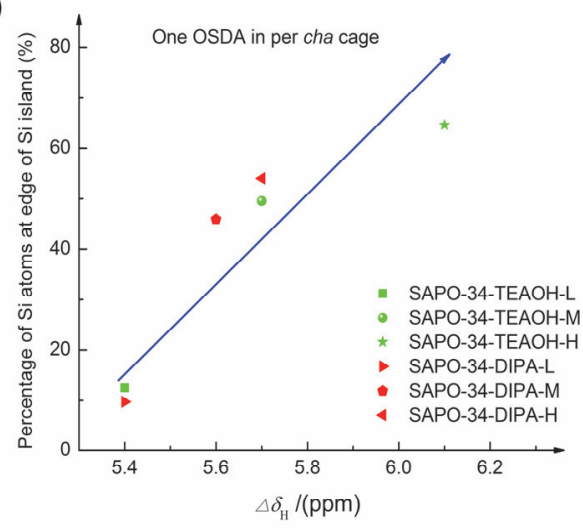

SAPO-34-TEAOHs, even if the number of OSDA within one cha cage is identical and the Si contents are similar in both series.

Notably, compared with $\mathrm{TEA}^{+}$cation with an inborn positive charge, DIPAs are neutral molecules and supposed to be firstly protonated to balance the negative charges from the lessdefective frameworks of SAPO-34-DIPAs, which are confirmed by ss-NMR (Figs. 2, 3, and Figs. S3, S4 (SI)). In this case, when the $\mathrm{Si}$ contents are enhanced, the neutral DIPA is inevitably surrounded in the pure-silica cha cage, leading to a decrease in the acid density. In order to verify this hypothesis, SAPO-34DIPA-L and SAPO-34-DIPA-H were chosen for the hydrochloric acid treatment since the pure-silica domains remained intact after the acid etching ${ }^{28}$. As shown in Fig. S5 (SI), although both samples lose crystallinity after the acid treatment, SAPO-34-DIPA-H after post-treatment still maintained better framework structures than post-treatment SAPO-34-DIPA-L, which is consistent with ${ }^{29} \mathrm{Si}$ MAS NMR spectra results of post-treatment samples (Fig. S6 (SI)). This indicates that the pure-silica cha cages in the SAPO-34-DIPA-H indeed are present, Table S2 (SI) also shows that the neutral $\mathrm{Si}(0 \mathrm{Al})$ structure in SAPO-34-DIPA-L, SAPO-34-DIPA-M, and SAPO-34-DIPA-H are $3.1 \%, 13.7 \%$, and $22.9 \%$, respectively, however, in SAPO-34-TEAOH, even the SAPO-34-TEAOH-H has only $7.3 \% \mathrm{Si}(0 \mathrm{Al})$ structure in Si distributions. Therefore, the formed $\mathrm{Si}$ islands should be extensive and continuous in DIPA system. It is obvious that the more $\mathrm{Si}(0 \mathrm{Al})$ results in less density of BAs. The OSDA, which has a stronger protonated ability, will lead to less $\mathrm{Si}(0 \mathrm{Al})$ and thus increasing the density of BAs in one OSDA per cha cage system.

In addition, just as mentioned in the introduction, the strength of BAs is highly correlative of the $\mathrm{Si}(1-3 \mathrm{Al})$ structure, which is usually generated at the edge of the $\mathrm{Si}$ islands. In this case, we made a simple summation of the edge of the Si islands as shown in Table S2. The correlation relationship between the percentage of $\mathrm{Si}$ atoms on the periphery of $\mathrm{Si}$ islands and the $\mathrm{CD}_{3} \mathrm{CN}$ induced resonance shift $\Delta \delta_{\mathrm{H}}$ is presented in Fig. 4a. It can be seen that the percentage of $\mathrm{Si}$ atoms at the edge of Si islands in SAPO34-TEAOH series is higher than the corresponding ones of

(b)

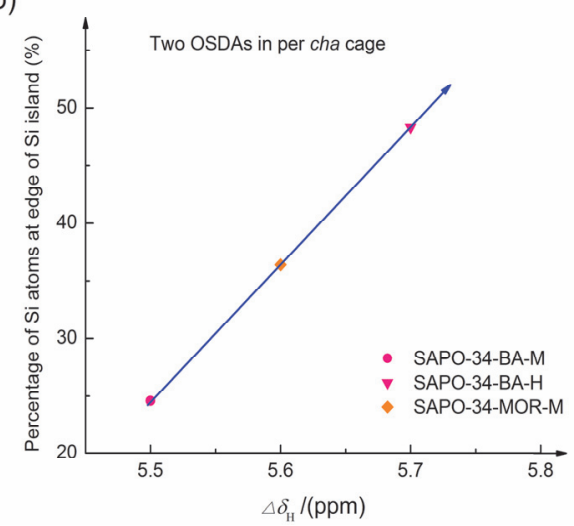

Fig. 4 The correlation relationship between the percentage of $\mathrm{Si}$ atoms at the edge of $\mathrm{Si}$ island and the $\mathrm{CD}_{3} \mathrm{CN}$-induced resonance shift $\triangle \delta_{\mathrm{H}}$ of SAPO-34 MSs templated by (a) TEAOH and DIPA, and (b) nBA and MOR. 
SAPO-34-DIPA series with similar Si contents. This may be attributed to more $\mathrm{Si}$ atoms on the periphery of $\mathrm{Si}$ island $\mathrm{Si}(1-$ $3 \mathrm{Al})$ ), resulting from the presence of more interrupted $\mathrm{Si}$ islands.

To further understand the influence of acid density and strength from OSDAs and Si contents, another two series of SAPO-34-nBA and SAPO-34-MOR were synthesized as shown in Table 1. Both scenarios are quite different from cases observed in SAPO-34-DIPA and -TEAOH. As a smaller bulk OSDA, SAPO-34 MSs synthesized by nBA have been evidenced that there are two OSDAs within one cha cage ${ }^{25}$. Besides, positions of MOR molecules in this work display the similar distribution, two OSDAs per cha cage, as investigated by TG and Rietveld refinement, respectively (Table 1 and Fig. 1b). For these two OSDAs, the secondary amine, MOR, has a higher protonated ability than the primary amine nBA. Therefore, the density of acids in SAPO-34-MOR-M is higher than the one of SAPO-34nBA-M with similar Si contents as demonstrated in Fig. 2c and Fig. 2d. However, the acid density of SAPO-34-nBA-H (1.09 $\left.\mathrm{mmol} \cdot \mathrm{g}^{-1}\right)$ with even higher Si content is less than the one of SAPO-34-nBA-M $\left(1.36 \mathrm{mmol} \cdot \mathrm{g}^{-1}\right)$. It might be attributed to the fact that more neutral $\mathrm{nBA}$ molecules, rather than protonated ones, are incorporated into the final product when the Si content increases in the initial gel composition. For SAPO-34-nBA and SAPO-34-MOR with two OSDAs occluded in one cha cage, the Si distribution could be viewed in Fig. $3 \mathrm{c}-\mathrm{d}$ and Table S2 and acid strength is shown in Fig. 2c-d and Fig. 4b. It could also be associated with the percentage of $\mathrm{Si}$ atoms on the periphery of $\mathrm{Si}$ islands.

\section{Conclusions}

By using multiple techniques, the acid properties of SAPO-34 MSs that synthesized by different OSDAs (TEAOH, DIPA, $\mathrm{nBA}$, and MOR) with various Si contents were comprehensively investigated. The TG and Rietveld refinement show that there is only one OSDA in each cha cage in SAPO-34-TEAOH and DIPA series, while two OSDAs for SAPO-34s synthesized by $\mathrm{nBA}$ and MOR. The BAs densities of SAPO-34 MSs are determined by the total amounts of protonated OSDAs in cha cages. The strength of the BAs is highly associated with the $\mathrm{Si}$ contents and $\mathrm{Si}$ atoms at the edge of $\mathrm{Si}$ islands. All these findings are not only significant for understanding the generation of BAs in SAPO-34, but also shed new insights to choose an appropriate OSDA for synthesizing SAPO MSs with desired properties.

Supporting Information: available free of charge via the internet at http://www.whxb.pku.edu.cn.

\section{References}

(1) Lok, B. M.; Messina, C. A.; Patton, R. L.; Gajek, R. T.; Cannan, T. R.; Flanigen, E. M. J. Am. Chem. Soc. 1984, 106 (20), 6092. doi: $10.1021 / \mathrm{ja} 00332 \mathrm{a} 063$

(2) Liu, X.; Yan, N.; Wang, L.; Ma, C.; Guo, P.; Tian, P.; Cao, G.; Liu, Z. Microporous Mesoporous Mater. 2019, 280, 105. doi: 10.1016/j.micromeso.2019.01.047

(3) Yuhas, B. D.; Mowat, J. P. S.; Miller, M. A.; Sinkler, W. Chem. Mater. 2018, 30 (3), 582. doi: 10.1021/acs.chemmater.7b04891

(4) Tian, P.; Wei, Y.; Ye, M.; Liu, Z. ACS Catal. 2015, 5 (3), 1922. doi: 10.1021/acscatal.5b00007

(5) Yang, M.; Fan, D.; Wei, Y.; Tian, P.; Liu, Z. Adv. Mater. 2019, 31 (50), 1902181. doi: 10.1002/adma.201902181

(6) Beale, A. M.; Gao, F.; Lezcano-Gonzalez, I.; Peden, C. H. F.; Szanyi, J. Chem. Soc. Rev. 2015, 44 (20), 7371. doi: 10.1039/C5CS00108K

(7) Mohan, S.; Dinesha, P.; Kumar, S. Chem. Eng. J. 2020, 384, 123253. doi: 10.1016/j.cej.2019.123253

(8) Li, S.; Falconer, J. L.; Noble, R. D. Adv. Mater. 2006, 18 (19), 2601. doi: 10.1002/adma.200601147

(9) Rehman, R. U.; Song, Q.; Peng, L.; Wu, Z.; Gu, X. Chem. Eng. Res. Des. 2020, 153, 37. doi: 10.1016/j.cherd.2019.10.032

(10) Peng, Q.; Wang, G.; Wang, Z.; Jiang, R.; Wang, D.; Chen, J.; Huang, J. ACS Sustainable Chem. Eng. 2018, 6 (12), 16867. doi: 10.1021/acssuschemeng.8b04210

(11) Wang, L.; Li, W.; Schmieg, S. J.; Weng, D. J. Catal. 2015, 324, 98. doi: $10.1016 /$ j.jcat.2015.01.011

(12) Qiao, Y.; Wu, P.; Xiang, X.; Yang, M.; Wang, Q.; Tian, P.; Liu, Z. Chin. J. Catal. 2017, 38 (3), 574. doi: 10.1016/S1872-2067(17)62775-X

(13) Fan, D.; Tian, P.; Xu, S.; Wang, D.; Yang, Y.; Li, J.; Wang, Q.; Yang, M.; Liu, Z. New J. Chem. 2016, 40 (5), 4236. doi: $10.1039 / \mathrm{C} 5 \mathrm{NJ} 02351 \mathrm{C}$

(14) Aghamohammadi, S.; Haghighi, M. Adv. Powder Technol. 2016, 27 (4), 1738. doi: 10.1016/j.apt.2016.06.005

(15) Sadeghpour, P.; Haghighi, M. Particuology 2015, 19, 69. doi: 10.1016/j.partic.2014.04.012

(16) Marchese, L.; Frache, A.; Gianotti, E.; Martra, G.; Causà, M.; Coluccia, S. Microporous Mesoporous Mater. 1999, 30 (1), 145. doi: 10.1016/S1387-1811(99)00023-2

(17) Woo, J.; Bernin, D.; Ahari, H.; Shost, M.; Zammit, M.; Olsson, L. Catal. Sci. Technol. 2019, 9 (14), 3623. doi: 10.1039/C9CY00240E

(18) Tan, J.; Liu, Z.; Liu, X.; Han, X.; He, C.; Zhai, R. Microporous Mesoporous Mater. 2002, 53 (1), 97. doi: 10.1016/S1387-1811(02)00329-3

(19) Barthomeuf, D. Zeolites 1994, 14 (6), 394 doi: 10.1016/0144-2449(94)90164-3

(20) Yan, N.; Wang, L.; Liu, X.; Wu, P.; Sun, T.; Xu, S.; Han, J.; Guo, P.; Tian, P.; Liu, Z. J. Mater. Chem. A 2018, 6 (47), 24186. doi: 10.1039/C8TA08134D

(21) Smeets, S.; McCusker, L. B.; Baerlocher, C.; Elomari, S.; Xie, D.; Zones, S. I. J. Am. Chem. Soc. 2016, 138 (22), 7099. doi: 10.1021/jacs.6b02953 
(22) Vistad, Ø. B.; Akporiaye, D. E.; Taulelle, F.; Lillerud, K. P. Chem. Mater. 2003, 15 (8), 1650. doi: 10.1021/cm021318o

(23) Wu, J.; Zhao, H.; Li, N.; Luo, Q.; He, C.; Guan, N.; Xiang, S. CrystEngComm 2012, 14 (24), 8671. doi: 10.1039/c2ce26335a

(24) Petitto, C.; Delahay, G. Chem. Eng. J. 2015, 264, 404. doi: 10.1016/j.cej.2014.11.111

(25) Yan, N.; Xu, H.; Zhang, W.; Sun, T.; Guo, P.; Tian, P.; Liu, Z. Microporous Mesoporous Mater. 2018, 264, 55. doi: 10.1016/j.micromeso.2018.01.002

(26) Haw, J. F.; Hall, M. B.; Alvarado-Swaisgood, A. E.; Munson, E. J.; Lin, Z.; Beck, L. W.; Howard, T. J. Am. Chem. Soc. 1994, 116 (16), 7308. doi: 10.1021/ja00095a039

(27) Simperler, A.; Bell, R. G.; Anderson, M. W. J. Phys. Chem. B 2004, 108 (22), 7142. doi: 10.1021/jp0356741

(28) Qiao, Y.; Yang, M.; Gao, B.; Wang, L.; Tian, P.; Xu, S.; Liu, Z. Chem. Commun. 2016, 52 (33), 5718. doi: 10.1039/C5CC10070D 